\title{
RANCANG BANGUN ALAT PENGERING ANDALIMAN \\ DENGAN MENGGUNAKAN METODE QUALITY FUNCTION DEPLOYMENT (QFD)
}

\author{
Benedikta Anna Haulian Siboro', Rizal Horas Manahan Sinaga², \\ Devis Wawan Saputra Simanjuntak ${ }^{3}$ \\ ${ }^{123}$ Fakultas Teknologi Industri, Institut Teknologi Del \\ Email: benedikta.siboro@ del.ac.id
}

\begin{abstract}
Abstrak: Andaliman merupakan tanaman rempah khas Sumatera yang umum digunakan sebagai bumbu masakan tradisional Batak seperti arsik dan makanan khas lainnya. Dalam upaya memproduksi produk turunan andaliman, salah satu proses yang dilalui agar andaliman dapat digunakan sebagai bumbu jadi dan produk lain adalah proses pengeringan. Umumnya pengeringan andaliman dilakukan dengan tenaga surya atau alat pengering. Kondisi yang dialami saat ini pada UMKM Taman Eden 100 adalah lamanya waktu pengeringan dan kapasitas yang terbatas sehingga tidak mampu memenuhi demand dari bumbu arsik instan. Penelitian ini dilakukan dengan menerapkan metode Quality Function Deployment (QFD) melalui kuisioner yang dibagikan kepada pemilik dan pekerja di UMKM tersebut untuk mengetahui kebutuhan alat pengering yang diinginkan. Hasil dari QFD tersebut dipetakan kedalam House of Quality (HOQ) yang diharapkan menjadi gambaran dari alat pengering yang baru. Dari HOQ ini dihasilkan bahwa pengguna menginginkan sebuah alat pengering berkapasitas yang lebih besar dari sebelumnya yang memiliki alat pengontrol panas sehingga panas merata didalam ruang pengering.
\end{abstract}

Kata kunci: andaliman, bumbu arsik, Quality Function Deployment, House of Quality, aroma dan kadar air andaliman, alat pengering andaliman

\begin{abstract}
Andaliman is a typical spice plant of Sumatra that is commonly used as a spice for traditional Batak cuisine such as arsik and other special foods. In an effort to produce derivative products of andaliman, one of the processes that can be used as a finished spice and other products is the drying process. Generally, andaliman drying is done by solar power or dryer. The conditions currently experienced at the UMKM Taman Eden 100 are the long drying time and limited capacity so that they are unable to meet the demand of instant spices. This research was conducted by implementation of Quality Function Deployment (QFD) method through a questionnaire distributed to owners and workers at UMKM to determine the desirable desiccant needs. The results of the QFD are mapped into the House of Quality (HOQ) which is expected to be new dryer. From this HOQ, it is produced that the user wants a dryer with a larger capacity than before which has a heat control device so that the heat is evenly distributed in the drying chamber.
\end{abstract}

Keywords: andaliman, arsikflavour, Quality Function Deployment, House of Quality, flavor and water content of andaliman, dryer of andaliman

\section{PENDAHULUAN}

Andaliman

acanthopodium) adalah merupakan tanaman rempah yang bersifat endemik yang banyak tumbuh pada ketinggian sekitar 1.100 - 1.400 mdpl di daerah Kabupaten Toba Samosir, Humbang Hasundutan, dan Samosir, Provinsi Sumatera Utara (Pardede \& Manik, 2019).
Andaliman mengandung zanthalene, geranol asetat, terpenoid, senyawa aromatik, antioksidan, dan antimikroba sehingga sangat bermanfaat bagi bidang kesehatan juga industri. Tanaman andaliman memiliki ketinggian batang antara 3-8 meter dengan ciri-ciri berbulu halus dan berduri. Hasil survey dari penelitian tahun 2017 (Lumban Raja \& Hartana, 2017) oleh Lumban Raja dan 
Hartana terdapat 2 jenis andaliman yaitu Tuba Sihorbo dan Tuba Siparjolo. Panjang tangkai bunga jenis Sihorbo lebih pendek dibanding Tuba Siparjolo. Selain itu rasa getar Sihorbo lebih lama hilang dan lebih pedas dibanding Tuba Siparjolo. Tuba Sihorbo memiliki tinggi 4-5 m dengan diameter batang 7-9 $\mathrm{cm}$, batang berwarna abu-abu kehijauan; dahan muda berwarna merah tua kehijauan, berambut jarang gundul dan memiliki onak pada ibu tulang daun dengan kelopak bunga berwarna hijau kekuningan serta buah berwarna hijau.

Buah andaliman umumnya digunakan untuk memenuhi kebutuhan konsumsi rumah tangga sebagai bumbu masak seperti ikan mas arsik, natinombur, dan sangsang yang disajikan langsung melalui restoran khas Batak. (Khairunnisyah, 2018). Sejak awal tahun 2018, beberapa produk turunan andaliman telah dikembangkan dalam bentuk kemasan untuk dijadikan sebagai produk oleh-oleh oleh pengelola Taman Eden 100, seperti bumbu arsik instan(Panjaitan \& Manik, 2019), (Siahaan \& Manik, 2019). Taman Eden 100 adalah salah satu objek ekowisata di Kecamatan Lumban Julu Kabupaten Toba Samosir (Paramitha, Manik, \& Halog, 2019). Berdasarkan praktek yang sudah dilakukan di Taman Eden 100, bumbu arsik instan ini dibuat dari rempah-rempah umum seperti bawang merah, bawang putih, cabe, jahe, kunyit, kemiri, dan rempah khas Kawasan Danau Toba yaitu andaliman. Rempahrempah ini disortir, dicuci dan ditimbang sesuai dengan takaran yang sudah ditentukan. Langkah selanjutnya adalah proses pengeringan. Pengeringan merupakan proses pemindahan kandungan air yang dapat bertujuan untuk memperpanjang umur simpan rempah dan meminimalkan biaya distribusi (Napitupulu \& Tua, 2012). Setiap rempah-rempah ini memiliki kadar air dan struktur yang beragam, sehingga waktu pengeringan berbeda-beda. Contohnya, bawang merah yang digolongkan sebagai umbi lapis yang mengalami kekeringan bagian lapisan terluarnya, kemudian mengelupas sehingga mudah sekali mengalami susut bobot sekitar $25 \%$ selama penyimpanan untuk daerah tropis. Dari hasil uji coba yang dilakukan di Taman Eden diperlukan waktu 3-4 jam untuk mengeringkan bawang merah, bawang putih, cabe, jahe dan kunyit dengan menggunakan oven. Selain itu diperlukan waktu 10 jam untuk mengeringkan andaliman dengan menggunakan oven. Kadar air andaliman dan bawang hamper sama yaitu berkisar 67-71\% (Khairunnisyah, 2018) untuk andaliman dan 70-80\% untuk bawang merah (Komar, Rakhmadiono, \& Lina, 2001). Namun Wijaya menjelaskan bawang merah tidak tahan terhadap kekeringan. Menurut pemilik UMKM, pengeringan menggunakan panas matahari memiliki kelemahan dimana metode ini menyebabkan rasa ketir andaliman berkurang lebih banyak dibandingkan apabila dikeringkan menggunakan oven(Komar et al., 2001). Namun, apabila menggunakan oven, pekerja harus mengganti-ganti posisi andaliman karena panas oven tidak merata. Oleh karena itu dilakukan perlu dilakukan rancang ulang alat pengering andaliman dengan pendekatan Quality Function Deployment (QFD) yang berbasis konsumen untuk inovasi produk. Quality Function Deployment (QFD) merupakan sebuah sistem dibangun berdasarkan kebutuhan pelanggan yang diterjemahkan secara akurat ke dalam desain teknis, manufaktur, dan perencanaan produksi yang tepat sehingga tercipta desain produk baru. Produk baru dapat dapat berupa produk asli, produk inovasi, produk modifikasi dan merek baru. (Yustian, 2016). Langkahlangkah dalam struktur QFD dengan metodologi "The House of Quality" dijelaskan dalam Gambar 1. 


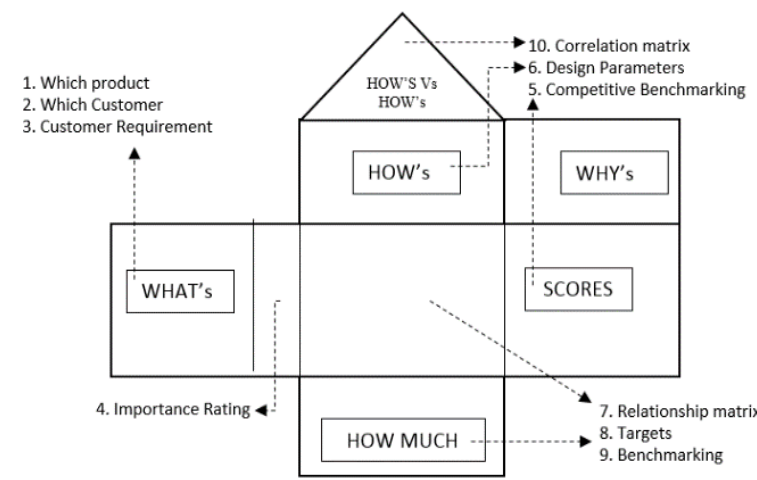

Gambar 1. Langkah Pengisian QFD (Cohen, 1995)

(WHAT's) merupakan input dalam karakteristik komponen (HOW's) dari desain produk sebagai acuan dalam melakukan proses manufaktur. How dijelaskan sebagai cara sejauh mana atau seberapa banyak target yang memungkinkan untuk dibuat. Dari kondisi, sistem QFD dianalisa dengan melihat fasefase yang saling terhubung yang dapat menggambarkan kebutuhan konsumen secara keseluruhan. Fase yang dimaksud adalah:

a. Matriks kebutuhan yang digunakan untuk mengklasifikasi kebutuhan pelanggan, mengumpulkan data-data kualitatif,, kuantifikasi data dan afinity diagram

b. Matriks perencanan yang dilakukan untuk mengukur kebutuhan-kebutuhan konsumen dan menetapkan tujuan performansi kepuasan

c. Respon teknis merupakan kegiatan mentransformasikan dan mengklasifikan kebutuhan-kebutuhan konsumen non teknis kedalam data teknis

d. Relationship matrik merupakan fase yang menganalisa tingkat hubungan respon teknis terhadap kebutuhan konsumen

e. Korelasi teknis merupakan aktivitas pemetaaan hubungan kepentingan antara karakterisitik respon teknis.

f. Penetapan target dan benchmarking, yang merupakan fase dalam menentukan respon teknis mana yang menjadi fokus perbaikan (direction of improvement) yang diperkuat pula dengan membandingkan produk yang akan dibuat dengan dengan produk pesaing.

Dalam membangun matriks hubungan QFD, diperlukan beberapa simbol yang menunjukkan hubungan dalam atribut (WHAT's) dari kebutuhan konsumen dan respons teknis (HOW's) seperti yang ditunjukkan pada Gambar 2.

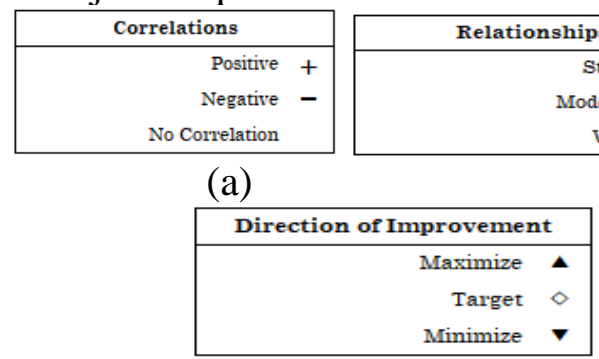

(c)

\section{Gambar 2. Simbol hubungan dalam QFD}

(Cohen, 1995)

Setelah HOQ terbentuk, maka dilanjutkan dengan perancangan konsep produk dengan melihat peluang-peluang pengembangan produk yang meliputi bahan, dimensi, jaminan, dan keunggulan dari produk pesaing yang didapat dari hasil QFD.

\section{METODE PENELITIAN}

Dalam usaha untuk membuat rancang bangun alat pengering andaliman ini, sebuah penelitian awal telah dilakukan di UMKM yang memproduksi produk oleholeh khas bumbu arsik Andaliman. Fokus penelitian ini adalah mengetahui kebutuhan pengguna (user requirement) dan permasalahan yang dihadapi pengguna dengan metode pengeringan yang ada selama ini. Dengan demikian dapatlah dirancang ulang alat pengering andaliman yang efektif dengan menerapkan metode QFD. Untuk menerapkan metode tersebut, kuisioner akan dibagikan kepada pengguna alat pengering yang biasa digunakan dalam hal in operator produksi dan pemilik UMKM sebanyak 4 orang. Kuisioner 
digunakan untuk mengetahui apa yang menjadi kebutuhan pelanggan. Data dari kuisioner ini akan digunakan untuk menyusun rumah kualitas atau House of Quality (HOQ) yang dimasukan sebagai table suara pelanggan atau Voice of Customer (VOC). Langkah selanjut adalah pengumpulan data respon teknis yang dari hasil wawancara dengan pengguna alat pengering yang kemudian dibangun $H O Q$ untuk rancang ulang alat pengering andaliman.

\section{HASIL DAN PEMBAHASAN}

\section{Identifikasi Kebutuhan Konsumen (Voice of Customer)}

Voice of Customer (VOC) merupakan langkah awal pembuatan HOQ yang menggambarkan keinginan konsumen terhadap alat pengering yang diperlukan untuk mengeringkan andaliman. Pada penelitian ini terdapat 12 atribut yang menjadi ekspektasi operator produksi dan pemilik UMKM (Gambar 3).

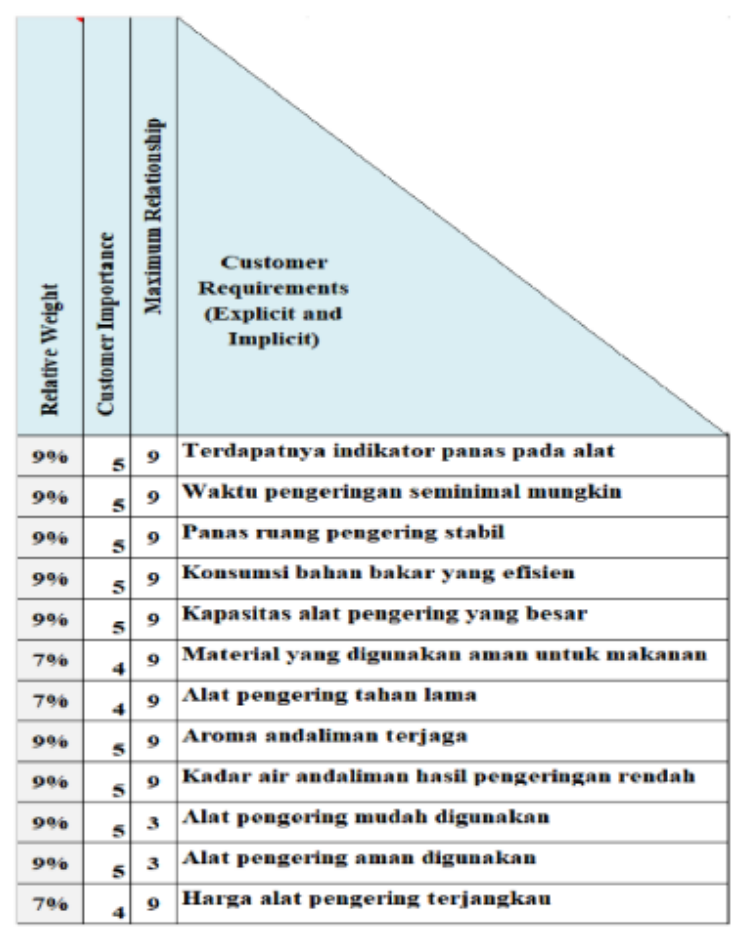

Gambar 3. Atribut Keinginan Pengguna Alat Pengering

Atribut yang dianggap penting oleh konsumen antara lain adanya indikator panas ruang pengering, waktu, aroma dan kadar air, alat aman dan mudah digunakan.

\section{Hubungan antara Customer Requirement dan Functional Teknis}

Matriks interaksi antara parameter teknik untuk alat pengering andaliman ditampilkan pada Gambar 4.

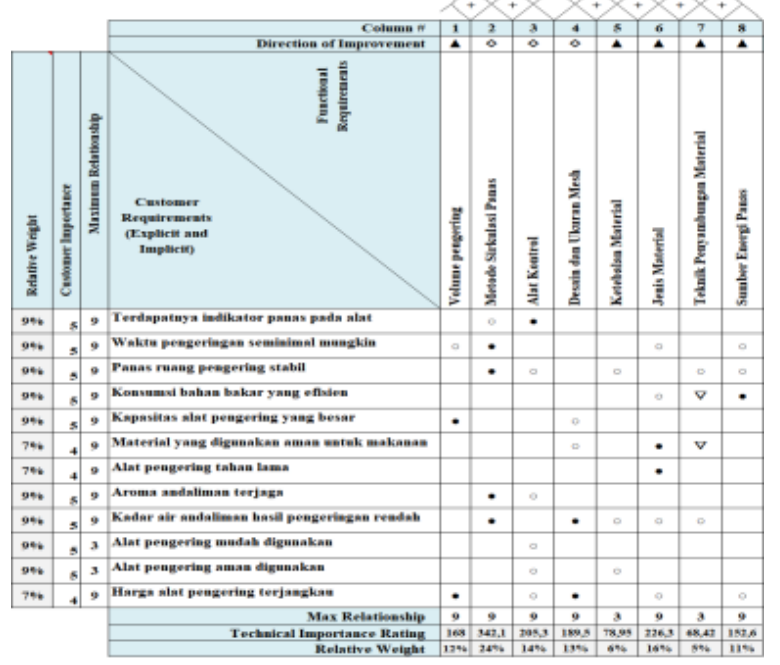

Gambar 4. Matriks hubungan Customer Requirement dan Functional Requirement

Dengan jenis volume pengering yang lebih besar, adanya sirkulasi panas yang baik, desain ukuran mesh untuk meletakkan andaliman, dan jenis material yang digunakan dalam membuat alat pengering akan menghasilkan alat pengering yang diharapkan konsumen. Dari gambar tersebut dapat dilihat juga hubunga antar functional requirement yang masingmasing memiliki hubungan positif dan negative yang berbeda-beda. Matriks diatas menghasilkan prioritas pengembangan dalam upaya peningkatan mutu alat pengering ini dengan melihat kebutuhan dari customer yang diurutkan sebagai berikut :
a. Metode sirkulasi panas $25 \%$
b. Jenis material $16 \%$
c. Alat kontrol $15 \%$
d. Desain ukuran mesh $11 \%$
e. Volume pengering $10 \%$
f. Sumber energi $10 \%$ 
g. Lain-lain seperti ketebalan material, dan teknik penyambungan $11 \%$

\section{Benchmarking}

Fase selanjutnya dalam QFD yang diperlukan dalam pengembangan alat pengering adalah melakukan analisa persaingan pasar dengan membandingkan beberapa produk kompetitor yang hasilnya ditunjukkan pada Gambar 5. Ada dua produk kompetitor yang dipilih, yaitu (i) alat pengering yang selama ini dipakai di UMKM tersebut, dan (ii) alat pengering yang dipakai di laboratorium produksi di sebuah universitas.

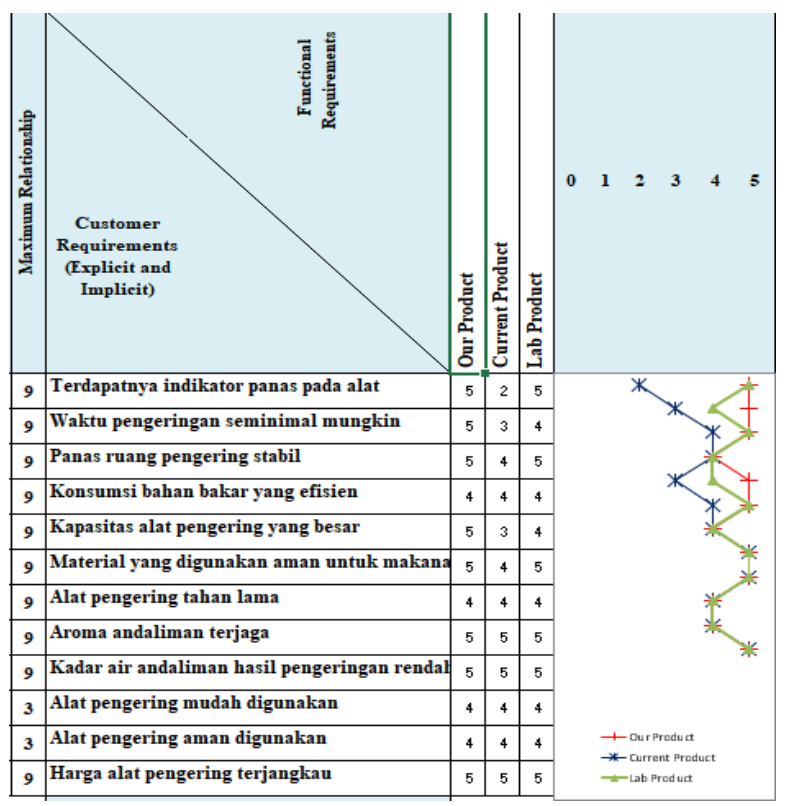

Gambar 5. Penilaian terhadap kompetitor

Dibandingkan dengan produk kompetitor, kapasitas dan waktu pengeringan menjadi unggulan yang akan didapat dari rancangan alat pengering baru. Alat pengering yang sudah digunakan sekarang masih berkapasitas kecil, dan tidak memiliki indicator panas dibandingkan dengan alat yang akan dirancang dan alat pengering lainnya. Penilaian kompetitor ini diperkuat juga dengan melakukan uji coba terhadap alat pengering kompetitor tersebut (Gambar $6)$.

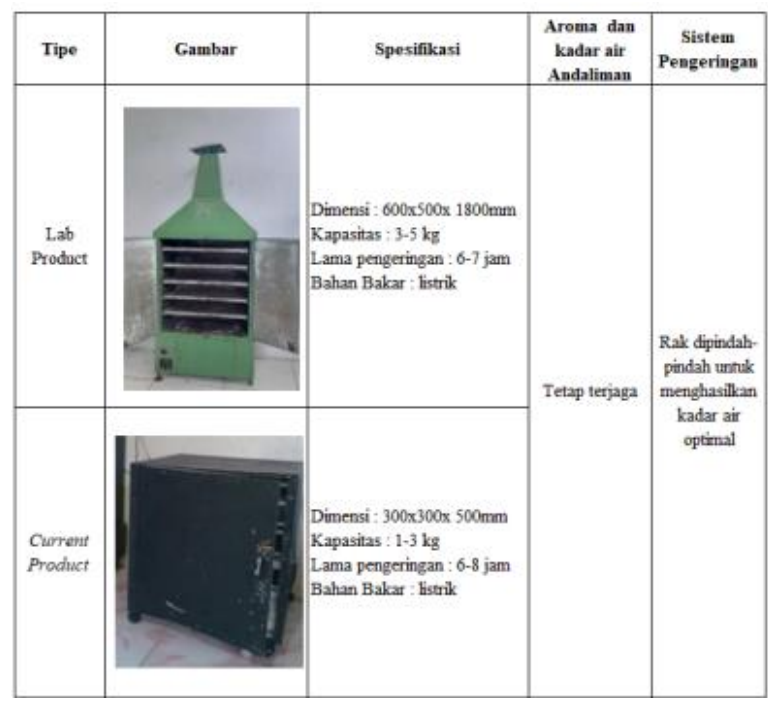

Gambar 6. Perbandingan uji pengering kompetitor

Desain baru alat pengering andaliman

Alat pengering andaliman dibuat berukuran $800 \times 900 \times 1650 \mathrm{~mm}$ yang terdiri dari 4 komponen yaitu :

1. Ruang pengering

Ruang pengeringan ini merupakan susunan dari dinding dan atap serta lantai yang terpisah dan digabungkan dengan menggunakan baut (knockdown) dan paku tembak. Masing-masing dinding dan atap terluar terusun dari rangka yang terbuat dari plat dengan ketebalan $1.2 \mathrm{~mm}$, sedangkan lantai ruang pengering menggunakan teablock dengan ketebalan $18 \mathrm{~mm}$ yang dilapisi dengan pelat stainless setebal $1 \mathrm{~mm}$. Akses masuk ruang pengering terdiri dari pintu dengan dan pada bagian bawah pintu dilengkapi dengan lubang udara yang berfungsi mensirkulasikan udara masuk ke ruang pengering. Kipas ditempatkan pada rangka bagian atas berfungsi untuk meratakan panas dan juga untuk mendorong uap air keluar dari ruang pengering (Rahayuningtyas dan Afifah, 2016). Alat ini dilengkapi dengan tombol manual on/off untuk pengoperasian kipas untuk alat pengering ini.

2. Pemanas 
Metode pengeringan yang paling umum dalam pengeringan produk pertanian, bahan makanan dan obat adalah pengeringan dengan udara panas (Afifah, Rahayuningtyas, Haryanto, \& Kuala, 2015). Dengan bantuan bahan bakar seperti gas, panas akan masuk melalui pelat dan rongga yang sudah dirancang dalam ruang pengering dan akan membuat andaliman lebih cepat kering.

3. Tray

Tray yang digunakan untuk meletakkan andaliman yang akan dikeringkan. Tray berukuran 480 x 480 x $50 \mathrm{~mm}$. Dimensi panjang tray diukur berdasarkan antropometri ukuran lebar bahu 4 operator. Pengukuran amtropometri dimaksudkan sebagai acauan dalam mendesain sarana dan prasarana kerja (Wijaya, Siboro, \& Purbasari, 2016). Tray disusun dalam 5 tingkatan. Jarak antara sumber panas dengan tingkatan terbawah tray adalah $15 \mathrm{~cm}$. Tinggi maksimum peletakkan tray ke tingkatan teratas adalah $1350 \mathrm{~mm}$ berdasarkan persentil 50 dimensi tinggi mata berdiri masyarakat Indonesia (Nurmianto, 1996). Tray pengering dibuat dan dirakit menggunakan baut dan mur. Tray tersebut berbentuk jarring/mesh dengan kerapatan 80 mesh.

4. Alat ukur

Alat ukur yang digunakan berupa thermocouple untuk mengukur besarnya suhu pada ruang pengering andaliman. Temperatur akan disesuaikan dengan suhu yang diperlukan untuk mengeringkan andaliman.

Potongan melintang dari alat pengering tersebut disajikan pada Gambar 7.

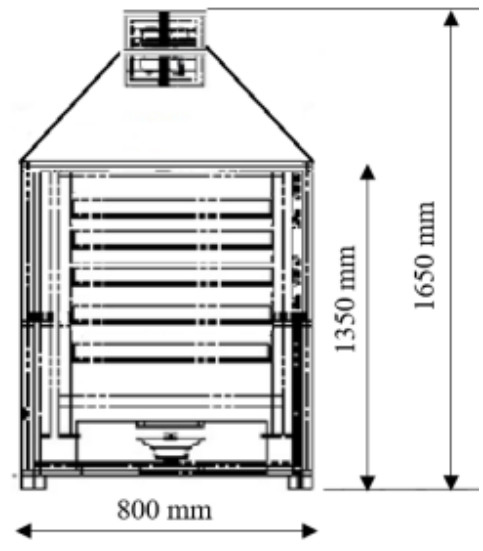

Gambar 7. Desain Alat Pengering tampak depan

\section{Uji coba alat pengering andaliman yang baru}

Uji coba alat pengering sudah dilakukan sebanyak 3 kali dengan kegiatan sebagai berikut:

1. Alat pengering dipapar dengan menggunakan bahan baku singkong dengan waktu pengeringan selama 4 jam dan suhu $90^{\circ}-110^{\circ}$. Hasilnya menunjukkan alat pengering ini dapat digunakan untuk tipe produk tersebut dengan waktu pengeringan yang singkat dan temperatur tinggi yang stabil.

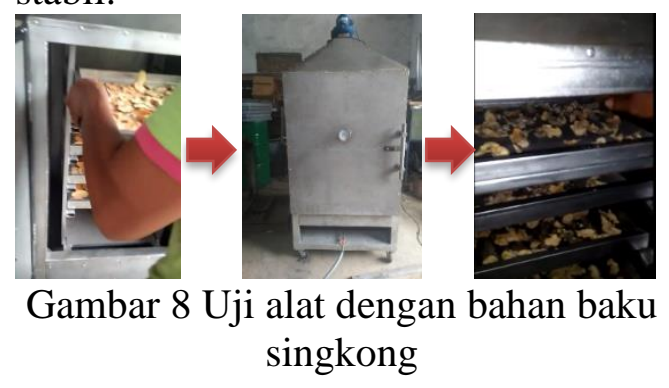

Hasil yang didapat dari pengujian pada bahan baku singkong ini adalah kondisi singkong yang dikeringkan dalam alat pengering benar-benar kering seperti kerupuk.

2. Alat pengering dipapar dengan menggunakan bahan baku andaliman dengan waktu pengeringan selama 7 jam dan pengaturan suhu $55^{\circ}$ dengan kapasitas yang dimasukkan sebanyak 9 $\mathrm{kg}$. 


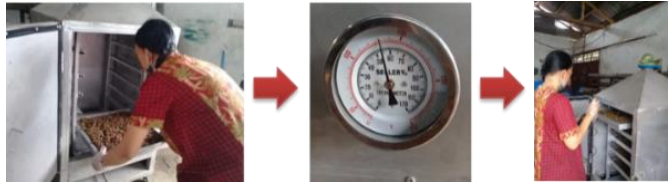

Gambar 9 Uji alat dengan bahan baku andaliman (I)

Selama 7 jam proses pengeringan, setiap jam dilakukan proses pengujian kadar air. Pada 3 jam pertama, kadar air andaliman masih merata berkisar 19$20 \%$. Mulai pada jam ke-4 dan 5 kadar air mulai menurun namun tidak merata berkisar 18-19\%. Kemungkinan ketidakrataan kadar air disebabkan terlalu banyak andaliman yang dimasukkan kedalam tray pengering sehingga panas tidak mampu menyerap air secara maksimal. Selanjutnya pada jam 6, kadar air sudah menunjukkan penurunan berkisar $17.5 \%-18 \%$ dan masih tidak merata. Kadar terendah terdapat pada daerah pinggiran tray, dan yang lain masih berkisar 18-18.5\%. Sebelum dilanjutkan proses pengeringan, andaliman dikurangi untuk mempercepat proses pengeringan. Sampai jam ke-7 kadar air masih berkisar $17 \%$.

3. Alat pengering dipapar dengan menggunakan bahan baku andaliman selama 6 jam dengan pengaturan suhu : $75^{\circ}, 75^{\circ}, 65^{\circ}, 65^{\circ}, 60^{\circ}, 60^{\circ}$ sebanyak $6 \mathrm{~kg}$

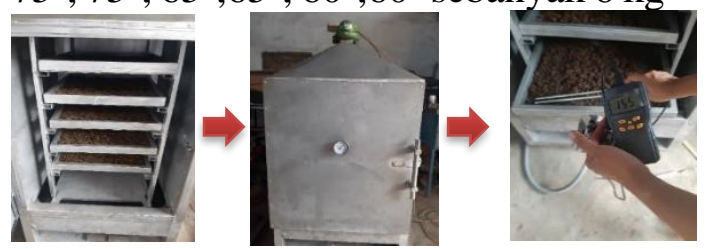

Gambar 10 Uji alat dengan bahan baku andaliman (II)

Kadar air awal pada andaliman berkisar $20 \%$. Selanjutnya dengan pengaturan $75^{\circ}$ pada dua jam pertama, kadar air menurun menjadi 18-19\%. Temperatur kemudian diturunkan sampai $65^{\circ}$ dan andaliman mulai diserak-serak agar kekeringan andaliman merata. Pada 4 jam pengeringan kekeringan andaliman sudah mencapai 17\%. Lalu untuk mencapai kekeringan yang diharapkan temperatur diatur menjadi $60^{\circ}$ pada jam ke-5 dan ke- 6 sehingga didapat kadar air berkisar $15-16 \%$.

\section{KESIMPULAN}

Penerapan metode QFD dalam merancang ulang alat pengering andaliman didapatkan 12 atribut dan 8 respon teknis yang dibutukan oleh konsumen. Selain itu terdapat 3 proritas utama pengembangan alat yang metode sirkulasi panas $25 \%$, jenis material 16\% dan alat kontrol 15\% sehingga dari prioritas tersebut, rancang ulang alat pengering memiliki 4 komponen utama yaitu ruang pengering yang memiliki sirkulasi panas merata, berbahan bakar gas, memiliki kapasitas besar dengan ukuran tray pengering yang cukup besar dan memiliki indikator panas.

\section{DAFTAR PUSTAKA}

Afifah, N., Rahayuningtyas, A., Haryanto, A., \& Kuala, S. I. (2015). Pengeringan Lapisan-Tipis Irisan Singkong Menggunakan Pengering Infrared. Pangan, 24(3), 217-224.

Cohen, L. (1995). Quality Function Deployment : How to Make QFD Work For You. Addison-Wesley Publishing Company.

Khairunnisyah, A. (2018). Pemanfatan andaliman (Zanthoxylum acanthopodium DC) sebagai tanaman penghasil minyak atsiri. Kultivasi, 17(1), 537-543. https://doi.org/https://doi.org/10.2419 8/kltv.v17i1

Komar, N., Rakhmadiono, S., \& Lina, K. (2001). Teknik Penyimpanan Bawang 
Merah Pasca Panen Di Jawa Timur. Jurnal Teknologi Pertanian, VOL. 2, $N O$ (penyimpanan bawang merah), 79-95.

Lumban Raja, R. D., \& Hartana, A. (2017). Variasi Morfologi Andaliman (Zanthoxylum Acanthopodium ) di Sumatera Utara. Floribunda, 5(7).

Napitupulu, F. H., \& Tua, P. M. (2012). Perancangan dan Pengujian Alat Pengering Kakao dengan Tipe Cabinet Dryer untuk Kapasitas 7,5 kg per siklus. Dinamis, $I I(10), 8-18$.

Nurmianto, E. (1996). Nurmianto_Konsep Dasar dan Aplikasinya.pdf. (I. K. Gunarta, Ed.). Jakarta: PT.Candimas Metropole.

Panjaitan, O., \& Manik, Y. (2019). Aplikasi Quality Function Deployment ( QFD ) dalam Mendesain Produk TALENTA Conference Series Aplikasi Quality Function Deployment ( QFD ) dalam Mendesain Produk Turunan Andaliman. Talenta Conference Series : Energy \& Engineering, 2(3). https://doi.org/10.32734/ee.v2i3.698

Paramitha, N., Manik, Y., \& Halog, A. (2019). Identification, Characterization and Stakeholder Analysis of Eco-tourism Destinations in Lake Toba Area. International Journal of Tourism and Hospitality in Asia Pasific, 2(81), 1-8.

Pardede, S. G., \& Manik, Y. (2019).

Peluang dan Tantangan Pengembangan Rantai Pasok bagi Peningkatan Nilai Produk Andaliman dari Kabupaten Toba Samosir. Talenta Conference Series : Energy \& Engineering, 2(4), 56-65. https://doi.org/10.32734/ee.v2i4.651

Siahaan, M., \& Manik, Y. (2019). Aplikasi Analisis STP (Segmenting, Targeting
, dan Positioning) dalam Merancang Strategi Pemasaran Produk Turunan Andaliman. Talenta Conference Series : Energy \& Engineering, 2(3). https://doi.org/10.32734/ee.v2i3.699

Wijaya, M. A., Siboro, B. A. H., \& Purbasari, A. (2016). Analisa Perbandingan Antropometri Bentuk Tubuh Mahasiswa Pekerja Galangan Kapal dan Mahasiswa Pekerja Elektronika. Profisiensi, 4(2), 108117. Retrieved from http://journal.unrika.ac.id/index.php/j urnalprofisiensi/article/view/593/454

Yustian, O. R. (2016). Analisis Pengembangan Produk Berbasis Quality Function Deployment (Qfd) (Studi Kasus pada Produk Susu PT MSA). Jurnal Ekonomi Dan Bisnis, 18(3), 23.

https://doi.org/10.24914/jeb.v18i3.279 